\title{
Electrical and mechanical properties of historical mortars in Bursa/Turkey
}

\section{Propiedades eléctricas y mecánicas de morteros históricos en Bursa / Turquía}

\section{Tayfun Uygunoğlu (Main and Corresponding Author)}

Afyon Kocatepe University, Engineering Faculty, Civil Engineering Department, 03200, Afyonkarahisar (Turkey)

1uygunoglu@aku.edu.tr

\section{illker Bekir Topçu}

Eskişehir Osmangazi University, Engineering Faculty, Civil Engineering Department 26480, Eskişehir (Turkey)

ilkerbt@ogu.edu.tr

\section{Emriye Çınar}

Osmaniye Korkut Ata University, Engineering Faculty, Civil Engineering Department 03200, Osmaniye (Turkey) emriyecnar@gmail.com

\section{Doğucan Resuloğulları}

University of East London, School of Architecture, Computing and Engineering, London (United Kingdom)

dogucanresul@gmail.com

Manuscript Code: 1080

Date of Acceptance/Reception: 06.02.2019/17.02.2018

DOI: $10.7764 / R D L C .1 .1 .54$

\section{Abstract}

This paper focuses on the electrical, physical and mechanical characterization of the ancient mortar (khorasan mortar) materials of precious structures, the Ali Paşa bathhouse, Çandarlı Ibrahim Paşa bathhouse, Hasan Paşa bathhouse, Iznik Castle and Tophane rampart historical constructions located in the West of Turkey, in Bursa. An exhaustive description of the materials has been obtained to enriching the knowledge on historical construction materials. The definition of the physical and mechanical properties of the materials, sophisticated laboratory tests were performed such as compressive strength, point loading, weight loss in acid, specific porosity, density and water absorption tests. Microstructure investigations and electrical resistivity measurements were also performed on the ancient mortars. The good correlations were obtained between electrical resistivity and mechanical properties of historical mortars as result of relations between them. The experimental investigation has allowed a better understanding of the remote origin of these structures.

Keywords: Historical buildings, Khorasan mortar, electrical resistivity.

\section{Resumen}

Este documento se centra en la caracterización eléctrica, física y mecánica de materiales de mortero antiguo (mortero Khorasan) de estructuras preciosas, la casa de baños Ali Paşa, la casa de baños Çandarlı İbrahim Paşa, la casa de baños Hasan Paşa, el castillo Iznik y el dique Tophane en la histórica Edificios situados en el oeste de Turquía, en Bursa. Se ha obtenido una descripción exhaustiva de los materiales para enriquecer el conocimiento sobre materiales de construcción históricos. La definición de las propiedades físicas y mecánicas de los materiales, se llevaron a cabo sofisticadas pruebas de laboratorio, tales como resistencia a la compresión, carga puntual, pérdida de peso ácida, porosidad específica, densidad y pruebas de absorción de agua. Investigaciones de microestructura y medidas de resistividad eléctrica también se realizaron en los morteros viejos Se obtuvieron buenas correlaciones entre la resistividad eléctrica y las propiedades mecánicas de los morteros históricos como resultado de las relaciones entre ellos. La investigación experimental ha permitido una mejor comprensión del origen remoto de estas estructuras.

Palabras clave: Edificios históricos, mortero Khorasan, resistividad eléctrica, caracterización.

Lime mortar that is used in construction of historic buildings is obtained by lime as binder material and filler as mixing aggregates (Binda et al., 2000; Duran et al., 2010). These mortars can be grouped as hydraulic and non hydraulic mortars (Elert et al., 2002). Non-hydraulic mortars which obtained by pure lime and non-pozzolanic aggregates is harden as a result of the lime transform to calcium carbonate with carbon-dioxide (Mertens et al., 2009). Also hydraulic lime mortar is obtained by mixing pozzolanic aggregate or using hydraulic lime or pure lime. The mortars that are prepared with hydraulic lime are hardened through the reaction of calcium silicates and calcium aliminumates in it with water and thus the formation of calcium silicate hydrate and calcium alimunate (Giileç \& Tulun, 1997). 
Protection of original materials with minimal intervention in restoration of historic buildings, forms the basis of modern conservation (Zeng et al., 2008). Today, "cement with mortar" that is used in repairing of historic buildings, increases corruption problem in the original materials because cement with mortar have different physical, chemical and mechanic properties (Pineda et al., 2013). Because of that the protection mortar should have similar physical properties with original mortar (Jackson et al., 2009). Characterization of ancient mortars can provide useful information about past technological knowledge and helps to elucidate how complex architectural structures were built and what construction phases were involved in their manufacture (Middendorf \& Knöfel, 1990). Many researchers carried out studies on historical mortars. Conte et al. (2017) investigated mortars from the Walls of S. Maria di Cerrate Abbey (South Italy) ranging in age from the 12th to the 20th century. Result showed that the mortars dated from the XVI-XVII centuries display a mixed siliciclastic-carbonate binder whereas mortars from the XIX-XX centuries exhibit a predominantly carbonate binder with the aluminium-silicates mostly gathered as lumps. Moropoulou et al. (2003) investigated uses multivariate statistics in an attempt to classify historical mortars in different groups, depending on their physicochemical characteristics. The results gave useful information on the understanding of the technology of historical mortars and planning syntheses for restoration ones. Paama et al. (1998) characterized historical mortars by using thermal analysis (TG-DTG), simultaneous infrared spectroscopy (TG-FTIR) and inductively coupled plasma atomic emission spectrometry (ICP-AES). They reported that TG-DTG analysis and FTIR methods can be used to identify various components of historical mortars. Ramos et al. (2015) used a methodology based on the Bayesian data fusion techniques applied to non-destructive and destructive tests for the structural assessment of historical constructions. They reported that a new concept of trust factor was developed to affect the uncertainty related to each test results depending on the higher or lower reliability of each test to predict a certain parameter. García-Florentino et al. (2017) proposed the HH-XRF as a fast in situ non-destructive technique (NDT) to classify historical mortars. They compared the accuracy of the semi-quantitative information provided by the HH-XRF spectrometer with a previously optimized WDXRF quantification method. Borges et al. (2014) presented two case studies of historical buildings in Lisbon coast, in which ancient lime mortars werehere used under severe seaside environmental actions. Mortar samples from these two case studies were characterized and the relationship of their composition with the good performance and high durability were discussed by authors. Lezzerini et al. (2014) aimed characterize the binder and aggregate fractions of mortar samples from the bell tower of the St. Nicholas church at Pisa, using X-ray fluorescence (XRF), X-ray powder diffraction (XRPD), simultaneous thermogravimetric/differential scanning calorimetry analysis (TG/DSC), optical microscopy (OM) and electron microscopy equipped with a microanalysis system (SEM/EDS). They obtained that the examined samples are hydraulic lime mortars with natural river sands (average binder/aggregate ratio 1:1). Böke et al. (2006) determined raw material compositions, basic physical, mineralogical, microstructural and hydraulic properties of some historic mortars and plasters by different methods. The results indicated that the mortars and plasters were hydraulic. It was also found that the bricks manufactured with high amounts of clays were consciously chosen in the preparation of hydraulic mortars and plasters. Schmid \& Dariz (2016) evaluated Raman microspectroscopic imaging technique for the analysis of historical mortars. According to their findings, Raman microscopy provides phase analysis of building materials with approximately $500 \mathrm{~nm}$ spatial resolution, enabling imaging of the spatial distributions of crystalline and amorphous phases as well as crystal orientations. Abu-Zeid et al. (2006) carried out the application of the Electrical Resistivity Tomography (ERT) technique, to evaluate restoration quality of the building foundations located in Venice (Italy). They recommended the ERT technique for characterization of ancient foundations as NDT method.

In this study, the investigations were carried out on electrical, physical and mechanical properties of the ancient mortar (khorasan mortar) materials of precious structures, the Ali Paşa bathhouse and Dervish, Çandarlı İbrahim Paşa bathhouse, Hasan Paşa bathhouse, Iznik Castle and Tophane rampart historical constructions located in the West of Turkey, in Bursa (Figure 1). General information about historical buildings are given below.

Figure 1. Display of the places where historical mortars are received on the map.

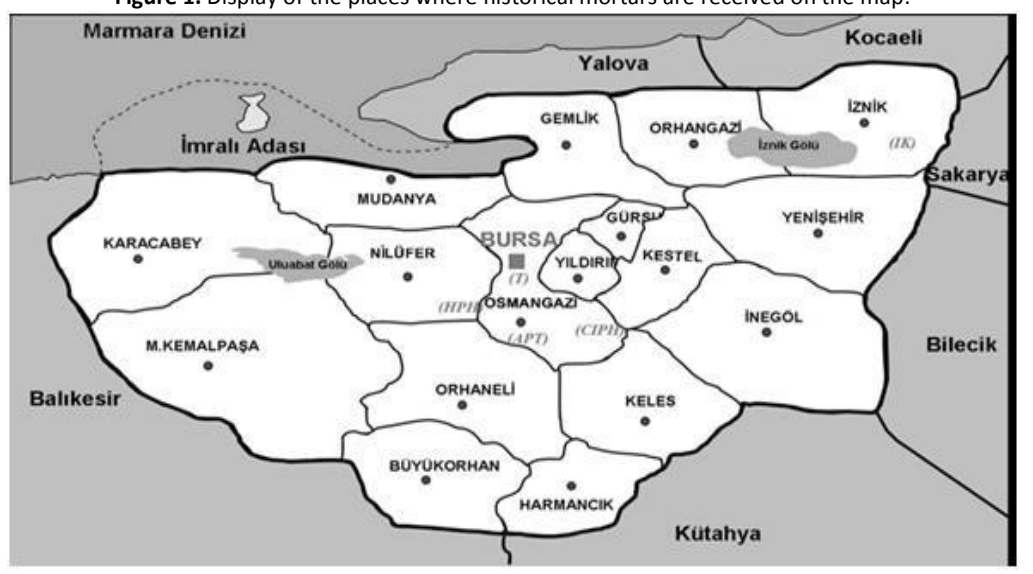


Alipaşa Mahallesi, Old Street number 14. Mosque XIV. was built by Çandarlı Hayrettin Paşazade Ali Pasha in the 16th century. According to the foundation date of 790-1394, the mosque was built in the previous year. It was built as a mosque and transformed into a gallery in 1551 (Hızlı, 2001).

\section{Çandarlı İbrahim Paşa Bathhouse (CIPH)}

In the Bursa Castle Grand Vizier Ibrahim Paşa who son of the Grand Vizier Çandarlı Halil paşa, built this bathhouse for his wife Hatice Hatun in second half of XV. Century. Entrance of bathhouse has a very high height and it is nested in two belt (Uzunçarşılı, 1986).

\section{Hasan Paşa Bathhouse (HPH)}

Bursa in Mudanya Hasan Paşa Bathhouse built at 1653. By Mudanya People "Upper Bathhouse" or "Old Bathhouse" as it is well known. This bathhouse built by Hasan paşa. This Bathhouse income goes to other foundations or another mosque. Bathhouse has a very large area size $\left(500 \mathrm{~m}^{2}\right)$. Its age is 400 years (Bursa Metropolitan Municipality, 2013).

\section{Iznik Castle (IK)}

The castle of Iznik dates from the Roman Empire period. It is near the lake of Iznik and in 310. It began to be built by Philip's son Antignius. In 330, the castle prevented enemy attacks. The castle undergone important repairs during the Byzantine period. The height of the castle is about 10-13 meters (TR Culture and Tourism Ministry, 2012).

\section{Tophane Walls (T)}

It started in the period of Prussia I, during the construction of the walls of Bursa dating back to the turn of 2200 years ago as a city state (police). The Bursa Walls, expressed by many historical sources made by the famous planner Hannibal, the first planner, represents an important example of the first and medieval city defense architecture (TR Culture and Tourism Ministry, 2013).

\section{Methodology}

Firstly, it was contacted to a Restoration Companies and received mortar samples from Ali Paşa bathhouse (APH), Ali Paşa Dervish (APT), Çandarlı İbrahim Paşa Bathhouse (CIPH), Hasan Paşa Bathhouse (HPH), Iznik Castel (IK) and Tophane walls $(T)$ in the Bursa region (Figure 2). Sampling points in wall shapes are defined to characterize founders such as mortars. After the samples were extracted, they were sealed with plastic bags. In the lab of Afyon Kocatepe University, Civil engineering department, mechanical, physical and electrical experiments were performed. Arithmetic average of three specimens was used for each experiment results.

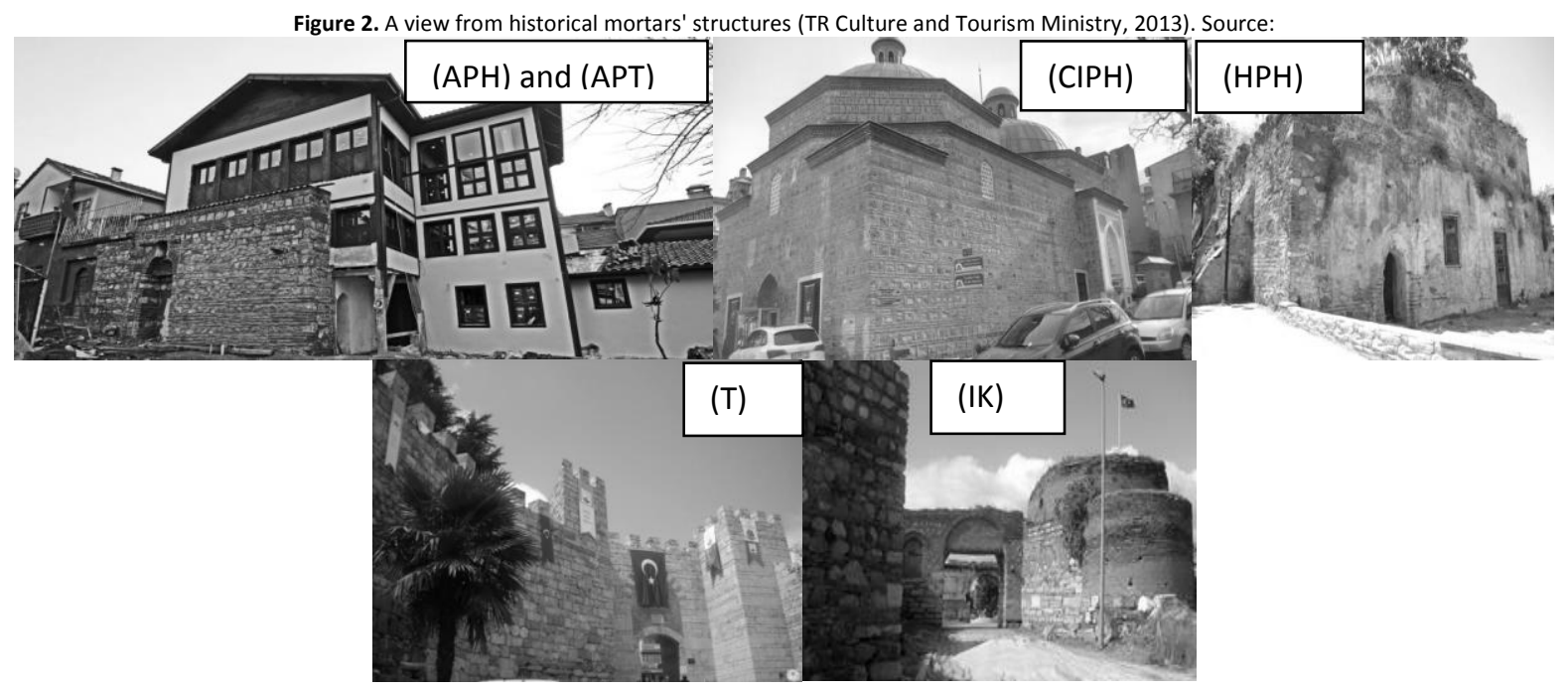




\section{Determination of mechanical properties}

The samples were cut in a spiral to be primarily square or rectangular prism (around $2 \mathrm{~cm}$ ) and got smooth surface for compressive strength test. Sample heights and spaces were measured using electronic calipers. In some of the samples, ultrasonic pulse velocity (UPV) test was performed first. Grease oil was applied to device probes and probes were placed to opposed surface of side surfaces. UPV was calculated using ratio of distance of probes to read time. Then, samples were applied uniaxial compression test with compression machine which has $100 \mathrm{kN}$ loading capacity (Figure 3-a). Pressure tests were carried out according to the methods specified in TS EN 772-1 (2015.). Compressive stress values were obtained by proportioning the load values to the areas.

In some parts of the samples, point load is done. The specimens placed between the two conical heads were loaded with the help of a manual arm (Figure 3-b). The load values of broken samples are broken in kilograms. The samples were subjected to a superficial pressure test secondly. Rectangular prismatic heads were attached. The samples were placed between the headers and pressure was applied with the help of a manual lever. The load values of broken samples are broken in kilograms. The point tensile strengths were calculated using these loads and areas.

Figure 3. (a) Compressive test and (b) point loading test on mortars.
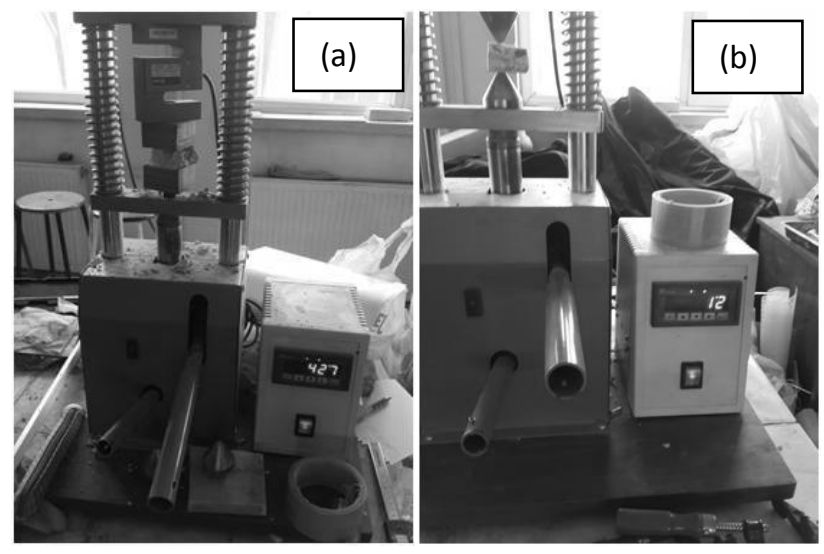

\section{Determination of physical properties}

Bulk density, absorbtion and porosity, which are the basic physical properties of the samples, were determined by using standard test methods. The specific gravity of the mortar was determined according to standard TS EN 480-11 (2008). Firstly, samples were given to furnace at heat $105^{\circ} \mathrm{C}$. After 24 hours samples were taken and found samples dry weight. Samples were placed to fully water containers. After 24 hours samples were taken and samples surface were dabbed. Water-saturated surface dry samples were weighed by help employees weigh the Archimedes principles. Subsequently, their weights in water were determined and the apparent specific gravity, water absorption capacity and porosity values were calculated. Then all of the dry samples were left in hydrochloric acid. The acid-insoluble fraction was filtered through filter paper and dried until the weight reached a constant weight at $105 \pm 5{ }^{\circ} \mathrm{C}(24 \mathrm{~h})$ and then weighted again. By taking advantage of the total amount of material, the amount of lime dissolved in the sample was calculated as the binder.

The samples were broken into small pieces for the ignition loss experiment. These pieces were placed in hightemperature resistant croissants. First of all, the samples were placed in the crucibles and the weights of the samples were taken. These samples were then placed in the oven. The furnace was gradually increased to $1000^{\circ} \mathrm{C}$ starting from room temperature. After the internal temperature of the oven reached $1000^{\circ} \mathrm{C}$, the samples were kept in the oven for 1 hour. After the oven had cooled to room temperature, the samples were taken. The weight differences of the samples were calculated by the difference between the final weight of the samples and the weight before the firing.

\section{Determination of microstructure of mortars}

Preparations were made so that small pieces can be taken from the samples and placed in the device. In this preliminary preparation, the samples were vacuumed and adapted to electron pulses. Properties were placed on the LEO 1430 VP model SEM device. LEO 1430 VP model SEM device works with W filament. Elemental analysis (EDX) was performed qualitatively and semi-quantitatively with the field method in the samples examined. 


\section{Electrical tests}

The test aimed to determine the differences in electrical resistivity measured at different types of historical mortars. To that effect, 6 different mortars were used. The mortar samples dried in furnace at $105{ }^{\circ} \mathrm{C}$ for $24 \mathrm{~h}$. The electrical resistivity was evaluated by direct measurement (two-point uniaxial) under AC with frequency of $100 \mathrm{~Hz}, 120 \mathrm{~Hz}, 1 \mathrm{kHz}$, $10 \mathrm{kHz}$ and $100 \mathrm{kHz}$, on the mortar specimens by LCR meter according to ASTM C 1760 (2012) (Figure 4). The mortar sample was placed between two electrodes (two parallel copper plates) with moist sponge contacts at the interfaces to ensure a proper electrical connection. The electrical resistivity (R) of concrete was calculated by Eq. (2) as follows.

Figure 4. Electrical resistivity measurement on samples (Şengül, 2014).

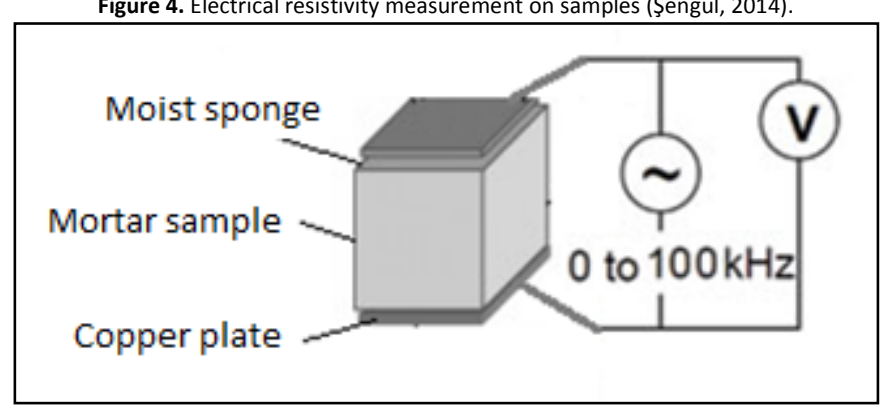

$\rho=R x \frac{A}{l}$

Where, $\rho$ is resistivity $(\Omega \cdot m), R$ is resistance $(\Omega)$, A is sample area $\left(\mathrm{cm}^{2}\right)$ and $/$ is sample length $(\mathrm{m})$.

Results and discussions

\section{Mechanical properties}

Variation in the compressive strengths of historic mortars (Figure 5); APH and APT in the same region have very close compressive strength values (about 7.5 MPa) and $\mathrm{CIPH}$ samples are over $7 \mathrm{MPa}$. IK and $\mathrm{HPH}$ mortars are about $6 \mathrm{MPa}$ and 4.2 MPa, respectively. The lowest compressive strength was also obtained at about $2 \mathrm{MPa}$ in T mortars. The historical mortar in Turkey is in the type of Khorasan mortar. As a result of the reaction of lime ( $\mathrm{CaO}$ ) and brick dust $\left(\mathrm{SiO}_{2}\right.$-based) with water $\left(\mathrm{H}_{2} \mathrm{O}\right)$, the structure of these mortars becomes a hydraulic binder with pozzolanic effect and gradually becomes calcium-silicate-hydrate (CSH). Thus, the increases in the strengths of historical mortars can also be shown as the measure of the realization of pozzolanic activity (Jasien'ko et al., 2016; Elsen, 2006). The low strength of $\mathrm{HPH}$ and T mortars compared to other historical mortars can also be stated to include more lime and less material in $\mathrm{SiO}_{2}$. For this reason, pozzolanic activities were limited and had low strength properties.

Figure 5. Compressive strength of historical mortars. Source:

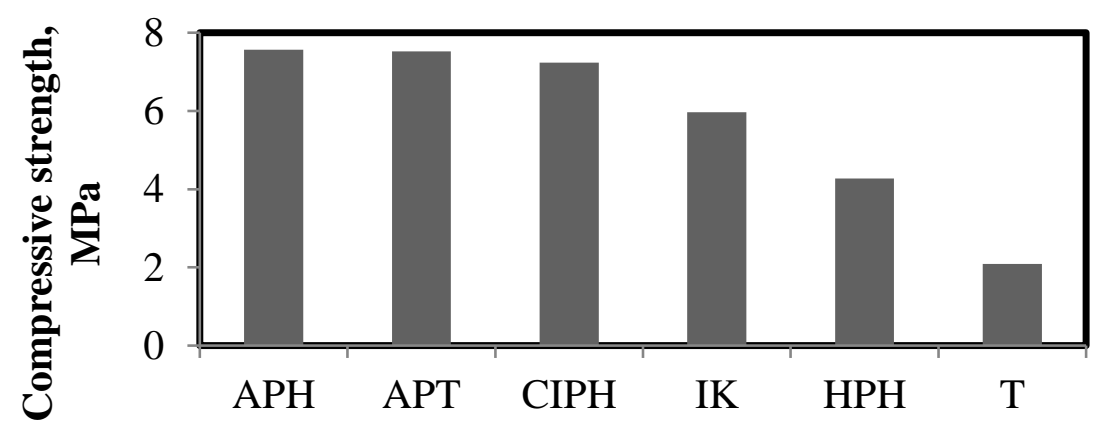

Historical masonry

Another characteristic which is determined on historical charges within the scope of mechanical properties is point strength (Figure 6). Indirect tensile strengths of the materials can be determined by spot testing. Similar to the compressive strength, APH, APT and $\mathrm{CIPH}$ have the highest tensile strength values at about $0.225 \mathrm{MPa}$ and the lowest 
point tensile strength at $0.09 \mathrm{MPa}$ in T mortars, as shown in Fig 6. One of the methods used to determine the properties of materials in a non-destructive manner is the UPV value. Transmission speed of the sound was determined by passing ultrasound from the historical mortar and presented in Figure 7. The high value of UPV indicates that the material is full and has a dense structure. In materials containing voids, the speed of voice transition is low and the strength values are low (Yaman et al., 2001). From here, when the historical fees are assessed; APH, APT and CIPH mortars have a more intensive structure than other mortars; $T$ is the result of the fact that the mortar contains more voids than the other mortars. Already the lowest strength values have been obtained for T. Taking into account the UPV values, HPH and T mortars are found in the very low quality class of materials whereas all other mortars are not included in the class of high quality materials in terms of strength (Tornsen, 1980).
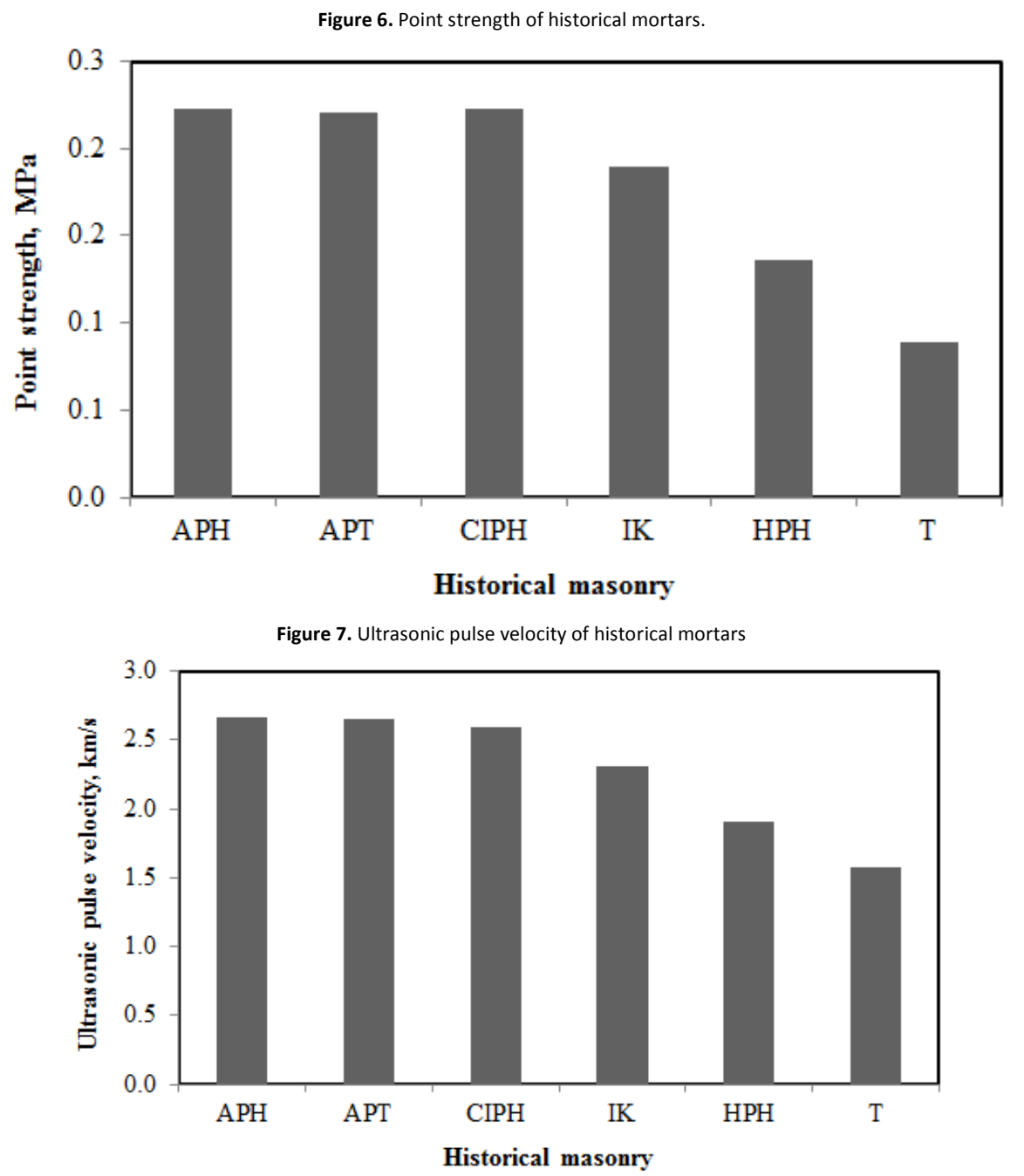

High correlations were obtained as a result of the linear relationship between the pressure resistance of the mortars and the point loading and UPV. Due to the strong correlation $(R=0.996)$ between the point tensile strength and the compressive strength of the mortar specimens (Figure $8 a$ ), it is possible to estimate the compressive strength in case of point loadings on mortars and also to estimate the compressive strength in case of determining the point strength by taking advantage of a small mortar sample. UPV is a non-destructive test method used for predicting concrete strength. High value correlations $(R=0.996)$ obtained from ultrasound experiments on mortar specimens support the use of UPV in pressure estimation (Figure $8 \mathrm{~b}$ ). The pressure resistance values of historical mortars of Bursa region can be determined by the following equation (2) and (3), respectively, using point load value and UPV value. 
Figure 8. Relation between compressive strength and a) point strength; b) ultrasonic pulse velocity.

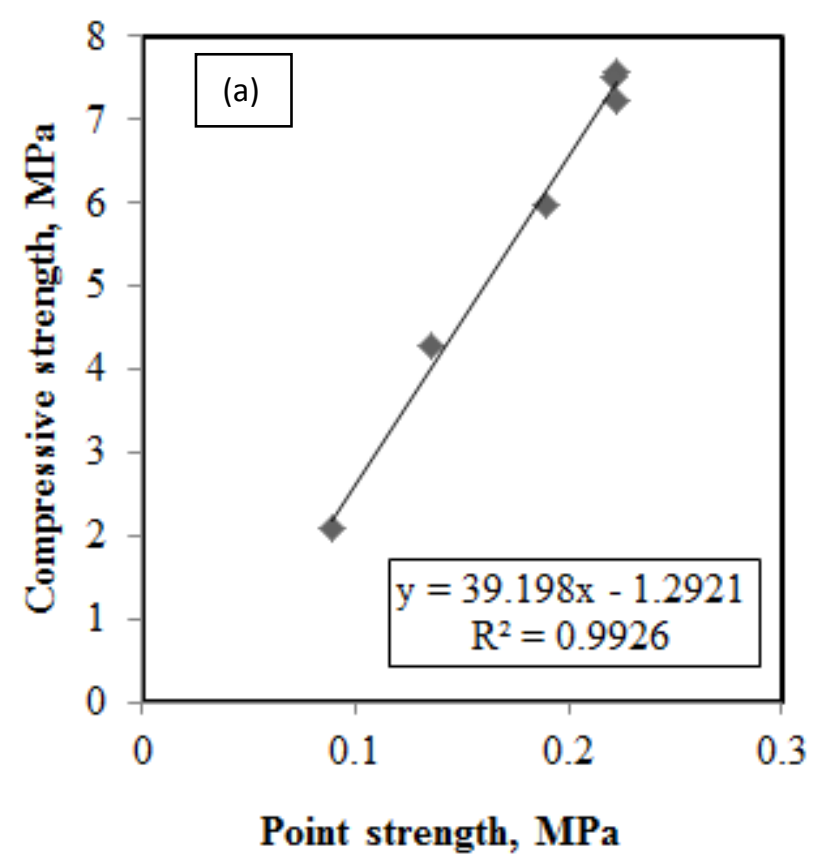

$\mathrm{f}_{\mathrm{c}}=39.198 \mathrm{P}_{\mathrm{t}}-1.2921$

$f_{c}=4.8461 U P V-5.2725$

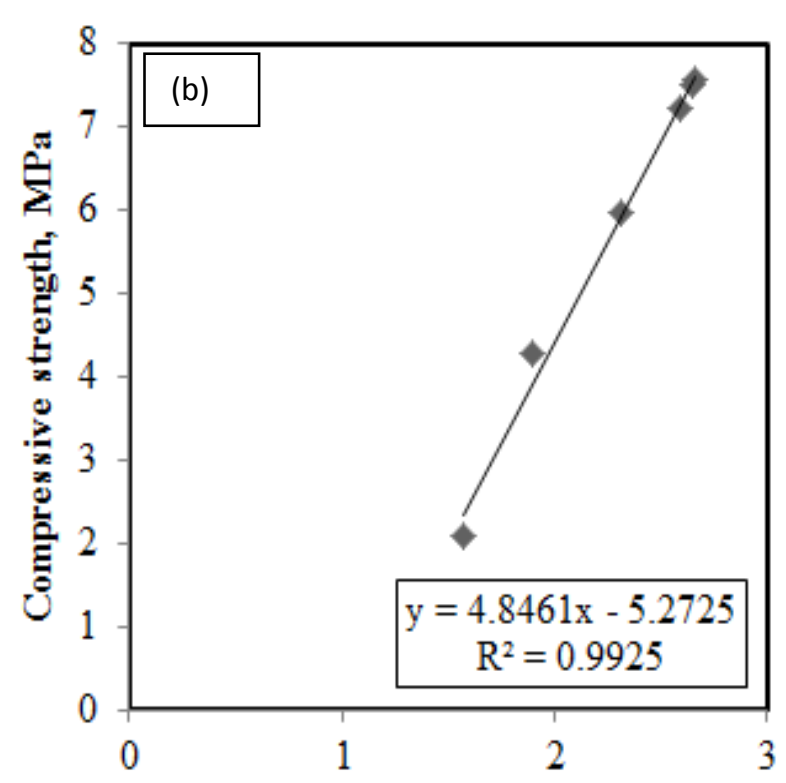

Ultrasonic pulse velocity, $\mathrm{km} / \mathrm{s}$

Where, $\mathrm{f}_{\mathrm{c}}$ is the compressive strength (MPa); Pt, point strength (MPa) and UPV represent the ultrasound transit speed $(\mathrm{km} / \mathrm{s})$.

Physical properties of historical mortars including weight water absorption, specific gravity, unit weight, apparent porosity, acid weight loss and ignition loss values are presented in Table 1 . The highest apparent porosity in the mortars was obtained at $T$ values of water absorption and ignition loss values. This property confirms that the compressive strengths of the T mortars and the UPV values are low.

\begin{tabular}{lcccccc}
\hline & $\begin{array}{c}\text { Table 1. Some physical properties of historical mortars. } \\
\text { absorption (\%) }\end{array}$ & $\begin{array}{c}\text { Specific } \\
\text { gravity }\end{array}$ & $\begin{array}{c}\text { Unit weight, } \\
\text { g/cm }\end{array}$ & $\begin{array}{c}\text { Specific } \\
\text { porosity (\%) }\end{array}$ & $\begin{array}{c}\text { Weight loss } \\
\text { in acid (\%) }\end{array}$ & $\begin{array}{c}\text { Loss of ignition } \\
(\%)\end{array}$ \\
\hline APH & 14.81 & 2.23 & 1.68 & 24.85 & 27.84 & 18.18 \\
APT & 15.18 & 2.32 & 1.72 & 26.07 & 25.01 & 25.00 \\
$\mathrm{CIPH}$ & 17.69 & 2.38 & 1.68 & 29.69 & 27.84 & 13.04 \\
$\mathrm{HPH}$ & 25.49 & 2.32 & 1.46 & 37.14 & 39.21 & 30.00 \\
$\mathrm{IK}$ & 21.72 & 2.40 & 1.58 & 34.29 & 19.64 & 19.05 \\
$\mathrm{~T}$ & 33.56 & 2.21 & 1.27 & 42.52 & 23.49 & 80.28 \\
\hline
\end{tabular}

\section{SEM/EDS analysis results}

SEM/EDS mineral analysis results of historical mortars are shown in Figure 9. Chemical composition analyses carried out by SEM/EDS indicated that these minerals were mainly composed of Oxygen (O), Calcium (Ca), silicon (Si), aluminum (Al) and iron (Fe) elements. SEM/EDS results show that the mortars were mostly composed of a high amount of calcite due to the carbonated lime and calcium silicate hydrates and, calcium aluminate hydrates due to hydraulic reaction of lime with the brick powders/aggregates (Elsen, 2006). 
Figure 9. SEM/EDS analysis test results of historical mortars.
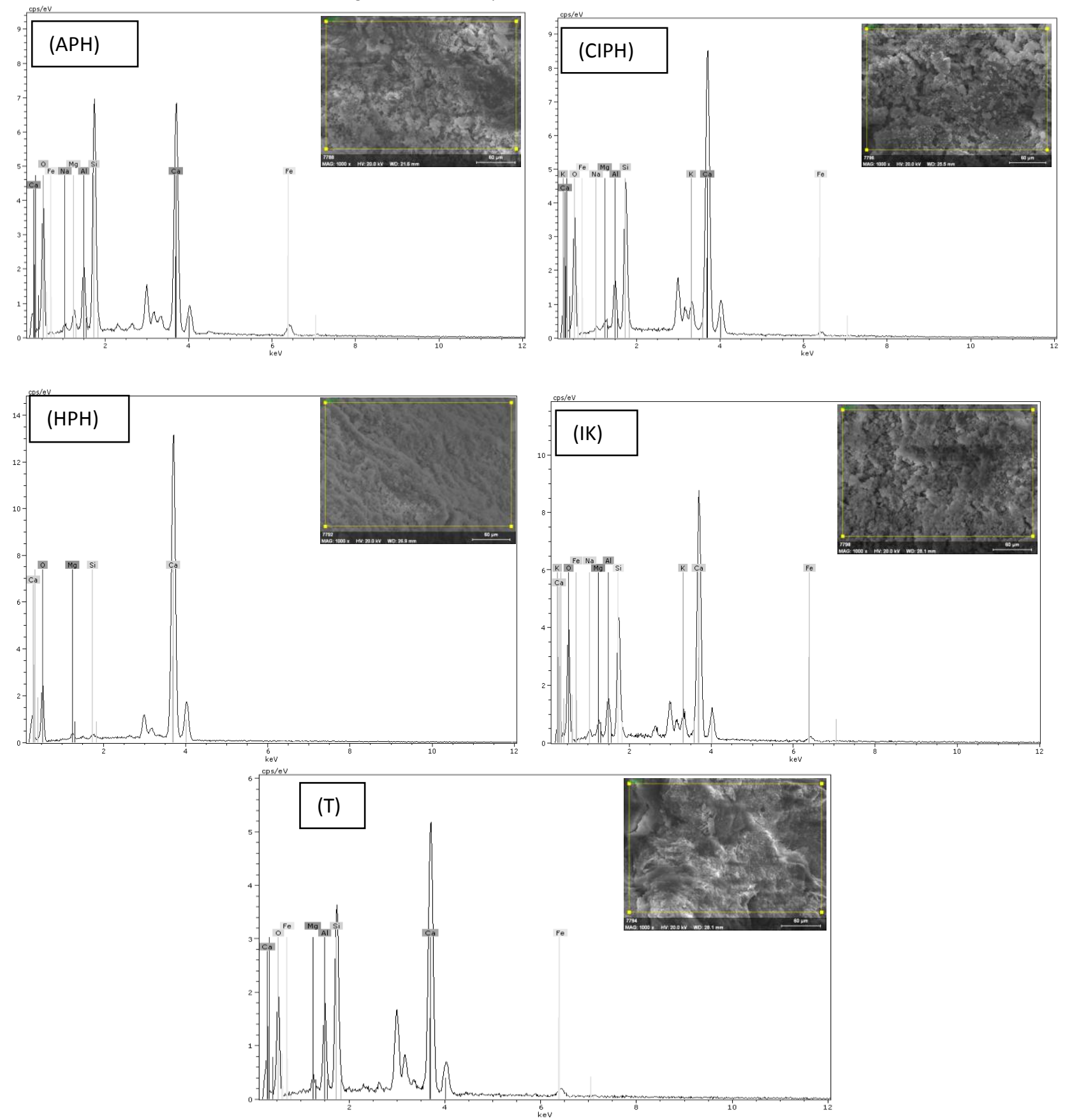

The distribution of the elements obtained as a result of the SEM/EDS analysis is summarized in Table 2. Calcium and silicon are the higher values of the main elements that provide the strength mechanisms of the mortars than the other elements due to pozzolanic activity. HPH mortars do not contain silicon based materials. Therefore HPH mortars are lime based. In other mortars, it is understood that lime as well as brick dust containing or fine brick aggregates are used.

Table 2. Element analyses of mortars.

\begin{tabular}{lccccc}
\multicolumn{7}{c}{ Table 2. Element analyses of mortars. } \\
\cline { 2 - 6 } Element & $\mathrm{APH}$ & $\mathrm{CIPH}$ & $\mathrm{HPH}$ & $\mathrm{IK}$ & $\mathrm{T}$ \\
\hline Oxygen & 74.06 & 75.8 & 75.62 & 76.36 & 76.91 \\
Sodium & 0.91 & 0.77 & 0 & 0.99 & 0 \\
Magnesium & 1.34 & 0.76 & 0.23 & 1.18 & 0.73 \\
Aluminium & 2.99 & 2.45 & 0 & 2.07 & 3.39 \\
Silicon & 9.9 & 6.19 & 0 & 5.26 & 7.49 \\
Calcium & 9.86 & 11.78 & 24.15 & 11.74 & 10.9 \\
Iron & 0.94 & 0.38 & 0 & 0.61 & 0.57 \\
Potassium & 0 & 1.87 & 0 & 1.79 & 0 \\
Total & 100 & 100 & 100 & 100 & 100 \\
\hline
\end{tabular}




\section{Electrical properties of historical mortars}

The electrical resistivity values of the khorasan mortars determined at different frequency values according to the mutual two plate method are given in Table 3. The reason for performing measurements at different frequency values is that the measurements at the selected frequency value in the field applications are different. In other words, the frequency value selected during the determination of the resistivity values of the materials directly affects the results (Silva et al., 2011).

In high-frequency measurements, mortars will have less resistance than low frequency measurements. Therefore, in this study, it is tried to show the possible electrical resistivity values of the historical charges at the selected frequency value. The electrical resistivity values of all mortars were lower as frequency increased. High electrical resistivity values were obtained in HPH and T mortars compared to other mortars. There may be different reasons for this. The high content of calcium in the HPH mortars is due to the fact that the high electrical resistivity is caused by the lime spoilage. Because of the high calcium content, the electrical resistivity value of the materials is also high (Şengül, 2014; Koleva et al., 2008). In other words, they are electrically insulating (Layssi et al., 2015; Buerchler et al., 1995). Figure 10 confirms this hypothesis with a high correlation coefficient $(R=0.978)$. When the relation between calcium content and electrical resistivity values of all mortars is established, it is obvious that the electrical resistivity values with calcium content also increase. Similar findings have been made in the literature (Şengül, 2014; Buerchler et al., 1995). The same is true for historic mortars. The rise in the electrical resistivity of the T mortars can also be attributed to the calcium content. However, the calcium content of T mortars is similar to other mortars. There is a different situation in T mortars. The reason why these mortars have high electrical properties is that the vacancy rates have the greatest value compared to other mortars. When the occupancy rate is lower, the conductivity properties of materials are also decreasing (Layssi et al., 2015; Koleva et al., 2008).

Table 3. Electrical resistivity of mortars depending on frequency.

\begin{tabular}{lccccc}
\hline \multicolumn{7}{c}{ Table 3. Electrical resistivity of mortars depending on frequency. } \\
\cline { 2 - 6 } Masonry & $0.1 \mathrm{kHz}$ & $0.12 \mathrm{kHz}$ & $1 \mathrm{kHz}$ & $10 \mathrm{kHz}$ & $100 \mathrm{kHz}$ \\
\hline APH & 2.43 & 2.41 & 2.28 & 2.07 & 1.60 \\
$\mathrm{APT}$ & 0.32 & 0.32 & 0.27 & 0.26 & 0.25 \\
$\mathrm{CIPH}$ & 7.06 & 6.94 & 6.34 & 4.75 & 2.43 \\
$\mathrm{HPH}$ & 205.74 & 199.23 & 115.31 & 50.28 & 16.48 \\
$\mathrm{IK}$ & 1.00 & 1.02 & 0.92 & 0.85 & 0.69 \\
$\mathrm{~T}$ & 338.65 & 334.96 & 258.16 & 139.47 & 49.48 \\
\hline
\end{tabular}

Figure 10. Relation between electrical resistivity and calcium content in historical mortars.

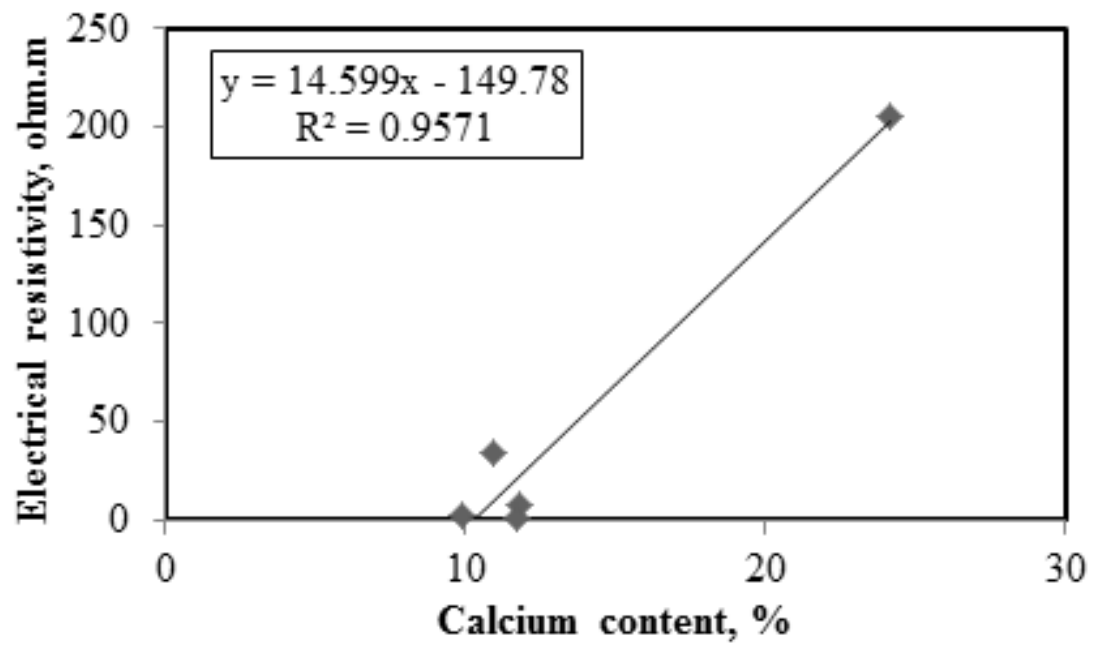

A remarkable property in Table 3 is that HPH and T mortars with high electrical resistivity values have low values in terms of pressure and point strength. HPH and T are high porous pozzolanic lime mortars. (Haslund and Nøst, 1998). Due to these properties of both charges (HPH and T), the electrical resistivities are high (Neithalath, 2007; Bigalke, 2000) [33-37]. As a result, the relationship between compressive strength and electrical resistivities of historical mortars was investigated (Figure 11). Comparing the compressive strength of the mortars with the electrical resistivities at different 
frequencies, high correlations were obtained. High electrical resistivity values were obtained in mortar with low pressure resistance. Therefore, as the electrical resistivity value increases, the value of the compressive strength decreases. The main reason for this is the decrease in resistance values due to the increase in the mortar voids in general (Bussian, 1983; Rust et al., 1999). Similar to the compressive strength, high correlation coefficients between the point resistances of historical mortars and electrical resistivity values are obtained (Figure 12). As the electrical resistivity value increases, the point resistance values of the mortars decrease. A remarkable feature in both compressive strength and point strength is the gradual decrease in the electrical resistivity in the case of high frequency values. The best correlation between the obtained correlations was obtained at resistances measured at $0.1 \mathrm{kHz}$ frequency and the lowest correlation at $100 \mathrm{kHz}$ frequency and the closest result in estimating mechanical properties was obtained at a frequency of $0.1 \mathrm{kHz}$. As a result, measuring electrical measurements at lower frequencies shows more accurate results. The equations that can be used to predict the compressive strength and the point strength values are given in Table 4 for each frequency value as a result of associating the mechanical properties with the electrical resistivity. If the mechanical properties of historical mortars of Bursa region can be determined and if the sample can not be taken in sufficient size, approximate values about compressive strength or point strengths can be obtained by determining the electrical resistivity value.

Table 4. Equations for compressive and indirect tensile strength of mortars depending on electrical resistivity.

\begin{tabular}{lcc}
\multicolumn{3}{c}{ Table 4. Equations for compressive and indirect tensile strength of mortars depending on electrical resistivity. } \\
\hline Frequency $(\mathrm{kHz})$ & Equation & Coefficient of correlation $(\mathrm{R})$ \\
\hline 0.1 & $\mathrm{f}_{\mathrm{c}}=-0.0146 \rho+7.1369$ & 0.9621 \\
1.0 & $\mathrm{f}_{\mathrm{c}}=-0.0201 \rho+7.0663$ & 0.9560 \\
10 & $\mathrm{f}_{\mathrm{c}}=-0.0374 \rho+7.0251$ & 0.9409 \\
100 & $\mathrm{f}_{\mathrm{c}}=-0.1065 \rho+7.0764$ & 0.9279 \\
& & \\
0.1 & $\mathrm{f}_{\mathrm{pt}}=-0.0004 \rho+0.2153$ & 0.9723 \\
1.0 & $\mathrm{f}_{\mathrm{pt}}=-0.0005 \rho+0.2132$ & 0.9581 \\
10 & $\mathrm{f}_{\mathrm{pt}}=-0.0009 \rho+0.212$ & 0.9382 \\
100 & $\mathrm{f}_{\mathrm{pt}}=-0.0027 \rho+0.2132$ & 0.9241 \\
\hline $\mathrm{f}_{\mathrm{c}}$ : compressive strength of masonry; $\mathrm{f}_{\mathrm{pt}}:$ point tensile strength; and $\rho:$ electrical resistivity of masonry.
\end{tabular}

Figure 11. Compressive strength of mortars depending on electrical resistivity.

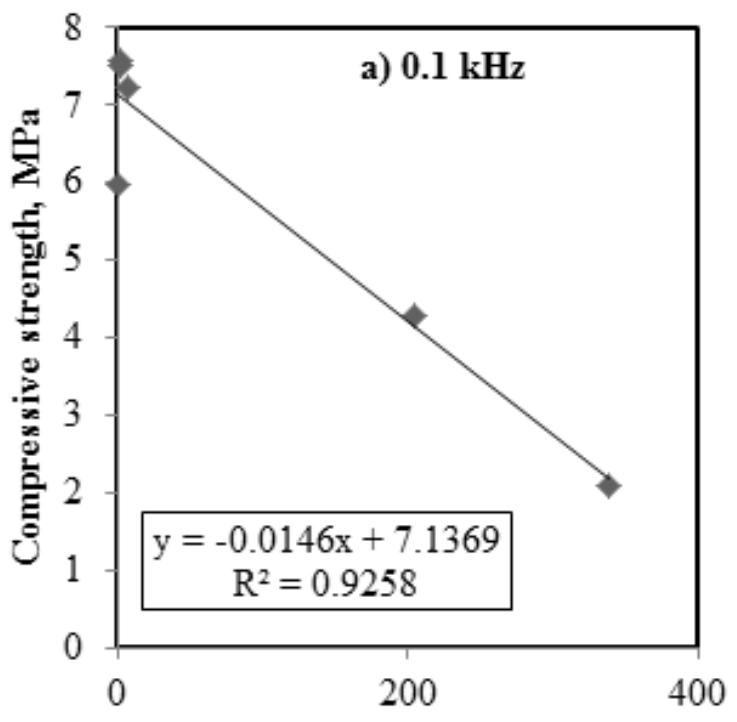

Electrical resistivity, k $\Omega . m$

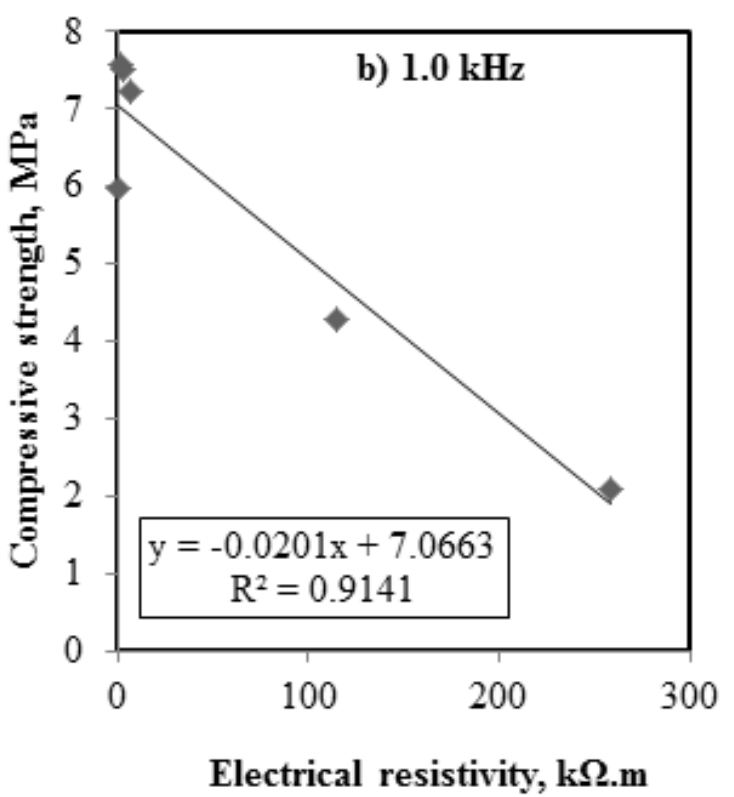




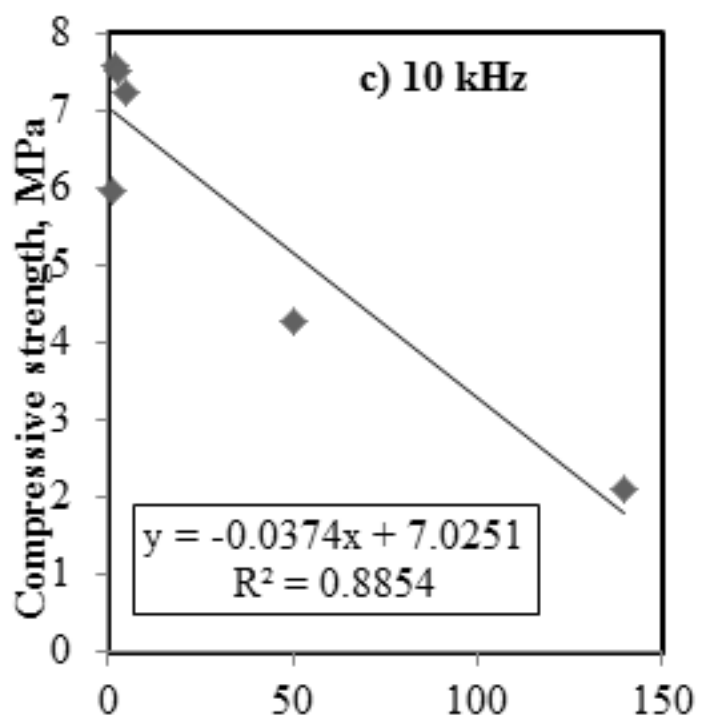

Electrical resistivity, k $\Omega . m$

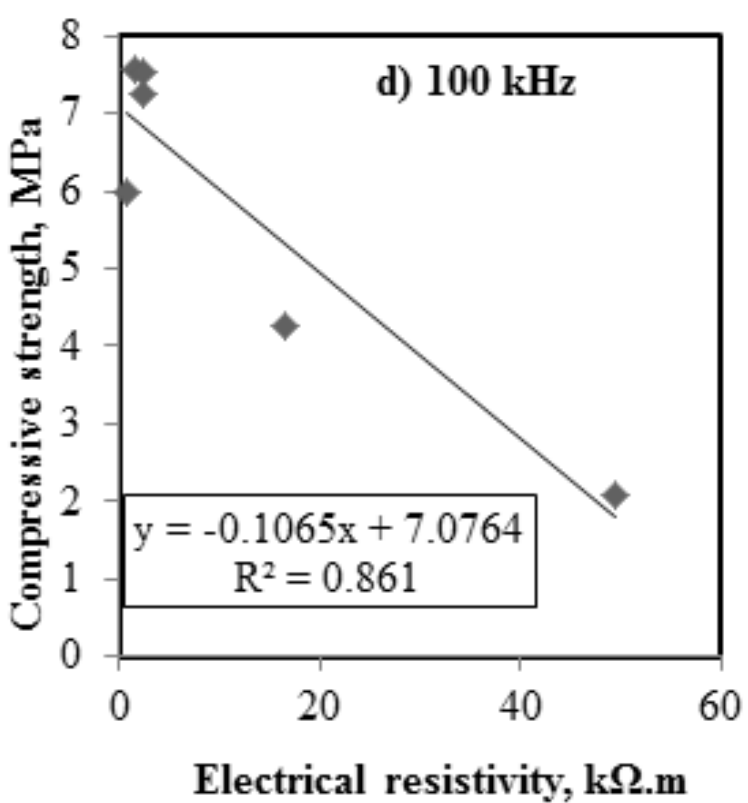

Figure 12. Point strength of mortars depending on electrical resistivity.
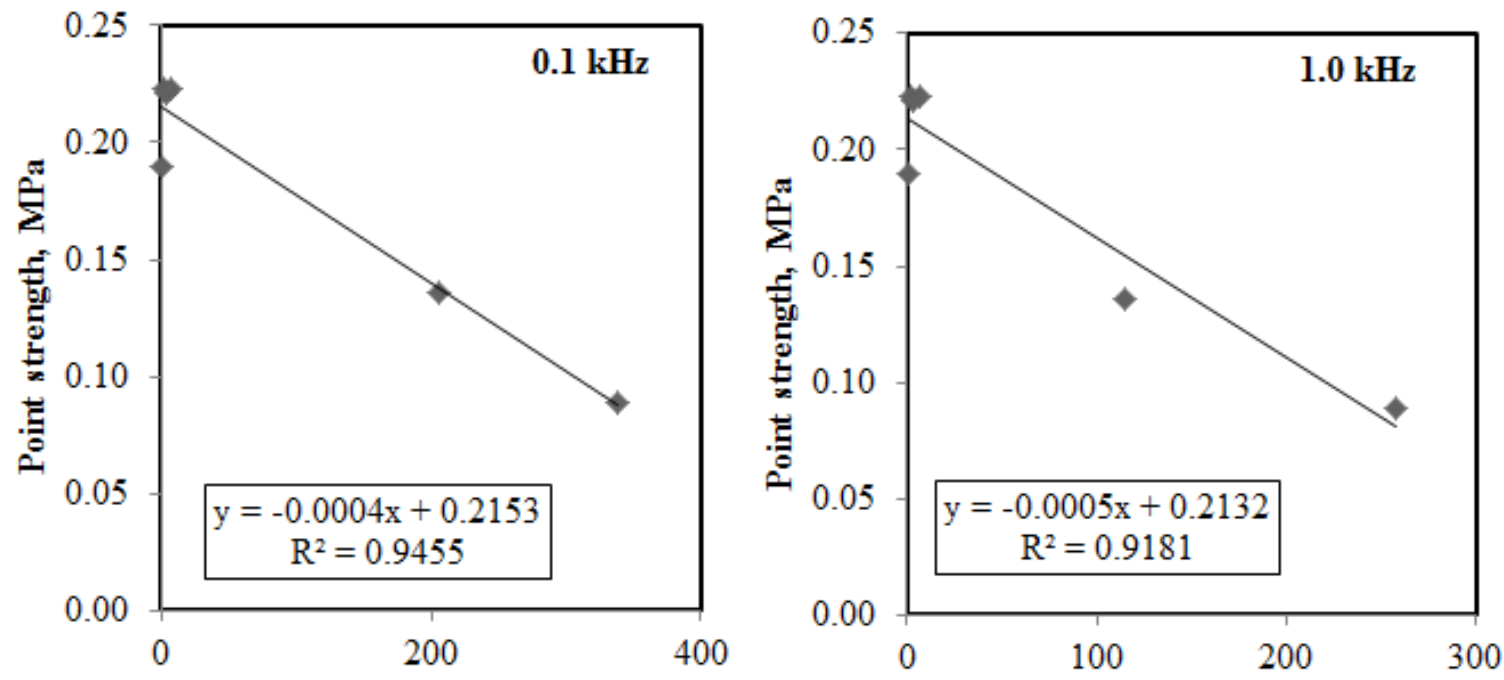

Electrical resistivity, k $\Omega . m$

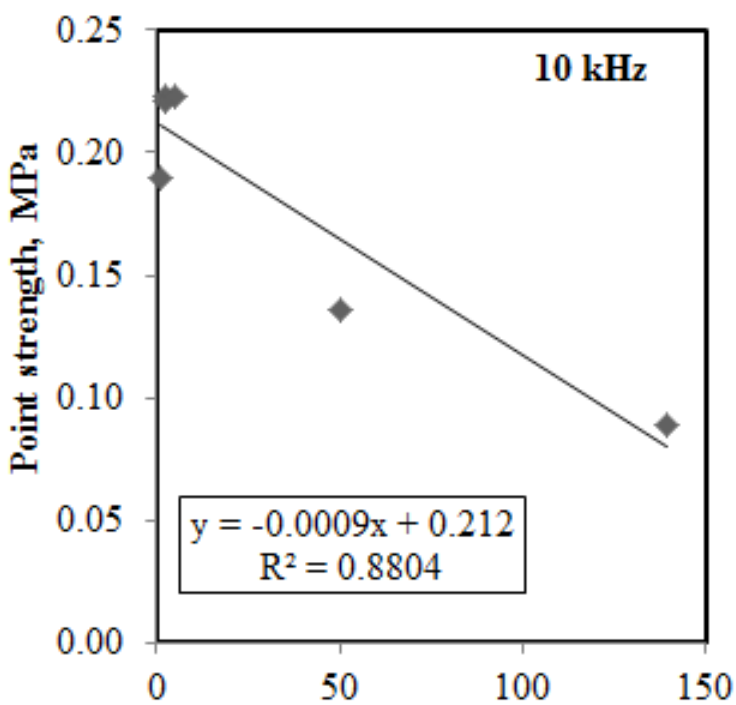

Electrical resistivity, k $\Omega . m$

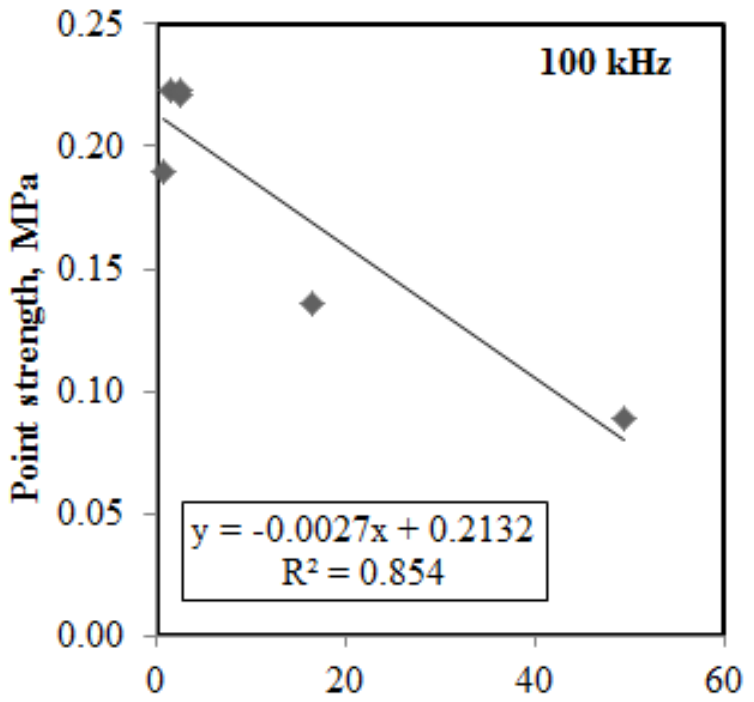

Electrical resistivity, k $\Omega . m$ 
In future studies, the surface electrical resistivities of the historical building materials can be measured and the physical and mechanical properties can be correlated and some properties of the historical structure can be obtained without being destroyed. However, further investigations will be needed because the mortars in the current building are both under load and affected by humidity conditions.

\section{Conclusions}

In this study, some investigations were performed on the physical and mechanical characterization of the ancient mortar (khorasan mortar) materials of historical constructions located in the West of Turkey, in Bursa. The obtained results were listed below.

- $\quad$ The APH and APT mortars tested have the highest compressive and point strength values, while the lowest values are obtained at T mortars. The compressive strengths of the mortars ranged from 7.5 to $2.0 \mathrm{MPa}$, while the point strengths ranged from 0.22 to $0.09 \mathrm{MPa}$.

- $\quad$ Significant relationships between compressive strengths of mortars and both UPV and point strength are obtained.

- The highest apparent porosity in the mortars is obtained in the T mortar with the values of water absorption and ignition loss.

- $\quad$ In the SEM / EDS analyzes of the mortars, calcium, silicon, aluminum and iron oxide are mainly found as main minerals. HPH was manufactured from lime mortar. Others were produced using lime and brick shavings or brick ballast. - $\quad$ Approximate electrical resistivity values of the historical mortars have been determined at different frequency values. The electrical resistivity values of all mortars were lower as frequency increased. High electrical resistivity values were obtained in HPH and T mortars compared to other mortars. The high content of calcium in the HPH mortars is due to the fact that the high electrical resistivity is caused by the lime spoilage. The reason why the electrical resistivities of T mortars are high is that the void ratios have the highest value compared to other mortars.

- $\quad$ The compressive strength and point strengths of the mortars are compared with the electrical resistivities of different frequencies and linear relations between them are revealed. High electrical resistivity values were observed in mortars with low strength. As a result of associating the mechanical properties with the electrical resistivity, equations were obtained which can predict the compressive strength and point strength values.

As a result, repair with similar material during rehabilitation for the preservation of historic structures is of great importance. In order to design these materials, the material of the current build must be analyzed very well. Historical mortars have a low strength value as a result of having high porosity even though they are lime mortar or pozzolanic mortar. Because of these properties, electrical resistivities are high values. As a result, the mechanical properties of existing building materials can be determined with high accuracy by determining the electrical resistivities.

References

Abu-Zeid, N., Botteon, D., Cocco, G. \& Santarato, G., (2006). Non-invasive characterisation of ancient foundations in Venice using the electrical resistivity imaging technique. NDT\&E International 39, 67-75.

ASTM C 1760. (2012). Standard test method for bulk electrical conductivity of hardened concrete. West Conshohocken (PA): ASTM.

Hızlı, M. (2001). The Imarat of Sultans in Bursa. Faculty of Theology, 10(1), 33-62.

Bigalke J., (2000). A study concerning the conductivity of porous rock. Phys. Chem. Earth, 25(2), 189-194.

Binda L., Saisi A. \& Tiraboschi C., (2000). Investigation procedures for the diagnosis of historic masonries. Construction and Building Materials, 14,199233.

Borges, C., Silva, A.S. \& Veiga, R. (2014). Durability of ancient lime mortars in humid environment, Construction and Building Materials, 66, 606-620.

Böke H., Akkurt S., ipekoğlu B. \& Uğurlu E. (2006). Characteristics of brick used as aggregate in historic brick-lime mortars and plasters. Cement and Concrete Research, 36(6), 1115-1122.

Buerchler D., Elsener B. \& Boehni H. (1995). Electrical resistivity and dielectric properties of hardened cement paste and mortar. Institute of Materials Chemistry and Corrosion, Swiss Federal Institute of Technology, ETHHbnggerberg, $\mathrm{CH}-8093$ Zurich.

Bursa Big City Municipality of Turkey $(2013$ a). The Bursa Ramparts. Retrieved from: https://www.kulturportali.gov.tr/turkiye/bursa/gezilecekyer/bursa-
surlari?fbclid=IwAROTZogLQ_MWhLM5GySsUPcrM9okITGIrma_quOnuBLMAPvkypf_AEAhjcA [In Turkish]

Bursa Big City Municipality of Turkey (2013 b). Hasan Paşa Hamamı. Retrieved from: https://emlakkulisi.com/mudanyadaki-tarihi-hasanpasa-hamamirestore-ediliyor/151197?fbclid=IwAR3_bIAEBwzIrbt1oXxRpdtTQPuMle3mxnOL_MfjkNAAZRai7wa3egVB1gs [In Turkish]. 
Bussian A.E. (1983). Electrical conductance in a porous medium. Geophysics, 48(9), 1258-1268.

Conte A.M., Corda, L., Esposito, D. \& Giorgi, E. (2017). Characterization of mortars from the medieval Abbey of Cerrate (southern Italy). Journal of Archaeological Science: Reports, 12, 463-479.

Duran A., Robador M.D. \& Perez-Rodriguez J.L. (2010). Study of the degradation on two historical buildings from northern Spain by the formation of oxalate and sulphate-based compounds. Int. J. Archit. Herit. 2012; UARC-2010-0290.R3.

Elert K., Rodriguez-Navarro C., Pardo S.E., Hansen E. \& Cazallo O. (2002). Lime mortars for the conservation of historic buildings. Studies in Conservation 47(1),62-75.

Elsen J., (2006). Microscopy of historic mortars - a review. Cement and Concrete Research 36,1416-1424.

García-Florentino C., Maguregui M., Morillas M., Marcaida I., Madariaga J.M. (2017). A fast in situ non-invasive approach to classify mortars from a construction of high historical value. Microchemical Journal, 133, 104-113.

Giileç, A. \& Tulun, T. (1997). Physico-chemical and petrographical studies of old mortars and plasters of Anatolia. Cement and Concrete Research, $27(2), 227-229$.

Haslund E. \& Nøst B. (1998). Determination of porosity and formation factor of water saturated porous specimens from dielectric dispersion measurements. Geophysics, 63(1) 149-153.

Uzunçarşıll, $\quad$ I.H. (1986). Çandarlı from: http://www.bursa.com/wiki/Candarli_Ibrahim_Pasa?fbclid=IwAR3i6W5iswDNamB4x1DqDyN4xj-I92xJwxNiBw1bTNUTY514N9xaP6h41eg [In Turkish].

Jackson M.D., Logan J.M., Scheetz B.E., Deocampo D.M., Cawood C.G., Marra F., Vitti M. \& Ungaro L. (2009). Assessment of material characteristics of ancient concretes, Grande Aula, markets of Trajan. Rome J. Archaeol. Sci., 36(11), 2481-2492.

Jasien'ko J., Logon' D. \& Misztal W. (2016). Trass-lime reinforced mortars in strengthening and reconstruction of historical masonry walls. Construction and Building Materials, 102(1), 884-892.

Koleva, D.A., Copuroglu, O., Breugel, K.V., Yea, G. \& Wit, J.H.W.D. (2008). Electrical resistivity and microstructural properties of concrete materials in conditions of current flow. Cement and Concrete Composites, 30(8), 731-744.

Layssi H., Ghods P., Alizadeh A.R. \& Salehi M. (2015). Electrical Resistivity of Concrete. Concrete International, 37(5), 41-46.

Lezzerini M., Legnaioli S., Lorenzetti G., Palleschi V. \& Tamponi M. (2014). Characterization of historical mortars from the bell tower of St. Nicholas church (Pisa, Italy). Construction and Building Materials, 69, 203-212.

Mertens G., Elsen J., Brulet R., Brutsaert A. \& Deckers M. (2009). Quantitative composition of ancient mortars from the Notre Dame Cathedral in Tournai (Belgium). Materials Characterisation, 60:580-5.

Middendorf B. \& Knöfel D. (1990). Use of Old and Modern Analytical Methods for the Determination of Ancient Mortars in Northern Germany, Proceedings of the 3rd Expert Meeting, Hamburg, Berlin. NATO-CCMS Pilot Study on Conservation of Historic Brick Structures. pp. 75-92.

Moropoulou, A., Polikreti, K., Bakolas, A. \& Michailidis, P. (2003). Correlation of physicochemical and mechanical properties of historical mortars and classification by multivariate statistics. Cement and Concrete Research, 33(6), 891-898.

Neithalath N. (2007). Extracting the performance predictors of Enhanced Porosity Concretes from electrical conductivity spectra. Cement and Concrete Research, 37(5),796-804.

Paamaa L., Pitkänen I., Rönkkömäkic I. \& Perämäkic P. (1998). Thermal and infrared spectroscopic characterization of historical mortars. Thermochimica Acta, 320(1-2), 127-133.

Pineda P., Robador M.D. \& Perez-Rodriguez J.L. (2013). Characterization and repair measures of the medieval building materials of a Hispanic-Islamic construction. Construction and Building Materials, 41, 612-633.

Ramos L.F., Miranda F., Mishra M., Fernandes F.M. \& Manning E. (2015). A Bayesian approach for NDT data fusion: The Saint Torcato church case study. Engineering Structures, 84, 120-129.

Rust A.C., Russell J.K. \& Knight R.J. (1999). Dielectric constant as a predictor of porosity in dry volcanic rocks. J. Volcanol. Geotherm. Res., 91 (1),7996.

Schmid T. \& Dariz P. (2016). Chemical imaging of historical mortars by Raman microscopy. Construction and Building Materials, 114, $506-516$.

Silva P.C., Ferreira R.M. \& Figueiras H. (2011). Electrical Resistivity as a Means of Quality Control of Concrete - Influence of Test Procedure. International Conference on Durability of Building Materials and Components, Portugal. April. pp. 12-15.

Şengül, Ö. (2014). Use of electrical resistivity as an indicator for durability. Construction and Building Materials, 73, 434-441.

Turkish Republic, Culture and Tourism Ministry (2012). Bursa Ansiklopedisi-Türkiye'de Vakif Abideleri Ve Eski Eserler 1.2.3. Retrieved from: https://www.kulturportali.gov.tr/turkiye/bursa/kulturenvanteri/znik-kalesi-vesurlar?fbclid=IwAR2BOCJaOn_2sSBfeFTDil_fDOYoWNQGmyzg48odjEa_BaxxvsLFUb6nluY [in Turkish].

Tornsen H.N. (1980). The Practical Use of Ultrasonic Pulse Velocity Measurements in the Assessment of Concrete Quality. Magazine of Concrete Research, 32(110), 7-15.

TS EN 480-11 (2008). Admixtures for concrete, mortar and grout - Test methods - Part 11: Determination of air void characteristics in hardened concrete. Turkish Standard Institute, Ankara, Turkey. 
TS EN 772-1+A1 (2015). Methods of test for masonry units - Part 1: Determination of compressive strength. Turkish Standard Institute, Ankara, Turkey.

Yaman I.O., İnci G., Yesiller N. \& Aktan, H.M. (2001). Ultrasonic Pulse Velocity in Concrete Using Direct and Indirect Transmission. ACI Materials Journal, 98(6), 450-457

Zeng Y.Y., Zhang B.J. \& Liang X.L. (2008). A case study and mechanism investigation of typical mortars used on ancient architecture in China. Thermochim Acta, 473 (1-2),1-6. 